Original Article

\title{
Abdominal ultrasound in amazonian manatee (Trichechus inunguis) (Natterer, 1883)
}

\author{
Ultrassonografia abdominal em peixe-boi amazônico (Trichechus inunguis) \\ (Natterer, 1883)
}

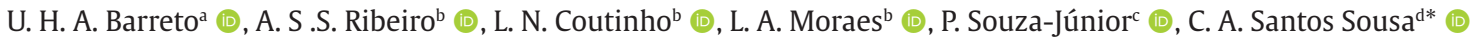 \\ and M. Abidu-Figueiredo ${ }^{\mathrm{a}}$ (D) \\ aUniversidade Federal Rural do Rio de Janeiro - UFRRJ, Departamento de Anatomia Animal e Humana, Seropédica, RJ, Brasil \\ bUniversidade Federal Rural da Amazônia - UFRA, Instituto da Saúde e Produção Animal, Belém, PA, Brasil \\ 'Universidade Federal do Pampa - UNIPAMPA, Departamento de Medicina Veterinária, Uruguaiana, RS, Brasil \\ dUniversidade Federal do Acre - UFAC, Centro de Ciências Biológicas e da Natureza, Rio Branco, AC, Brasil
}

\begin{abstract}
Morphophysiological species researches are fundamental, and diagnostic imaging is an excellent technique, already used in wild animals, with great application, not invasive and provide real-time information of each body. Amazonian manatees are on the list of endangered animals classified in the vulnerable category and knowledge of the normal pattern of ultrasound anatomy of organs and tissues is important for the maintenance and well-being of captive specimens contributing to reintroduction actions. The objective of the study was to standardize the examination technique and describe the ultrasound findings of the liver, gallbladder, stomach, urinary bladder and the subcutaneous tissue of the abdominal region in Trichechus inunguis, in order to contribute with the anatomical and sonographic knowledge and assist in the diagnosis and prognosis diseases. The study used 18 animals to describe the normal sonographic anatomy in the abdominal cavity of the Amazonian manatee. During abdominal scan, it was possible to visualize the features of the liver, gallbladder, stomach, urinary bladder obtained satisfactory results in this study. Therefore, other structures were not primarily identified by the reduced time, lots of fat and gases in intestines of animals.
\end{abstract}

Keywords: manatee, ultrasound, abdominal.

\begin{abstract}
Resumo
Pesquisas morfofisiológicas em espécies selvagens são fundamentais, e o diagnóstico por imagem é uma excelente técnica, já usada e com grande aplicação, não invasiva e que fornece informações em tempo real de cada órgão. Peixes-boi-amazônico encontram-se na lista de animais ameaçados de extinção classificados na categoria vulnerável e o conhecimento do padrão normal da anatomia ultrassonográfica de órgãos e tecidos é importante para a manutenção e bem-estar de espécimes em cativeiro contribuindo para ações de reintrodução. O objetivo deste estudo foi padronizar a técnica de exame e descrever os achados ultrassonográficos do fígado, vesícula biliar, estômago, vesícula urinária e o tecido subcutâneo da região abdominal em Trichechus inunguis, de modo a contribuir com o conhecimento anátomo-sonográfico e auxiliar no diagnóstico e prognóstico de doenças. O estudo utilizou 18 animais para descrever a anatomia ultrassonográfica normal na cavidade abdominal de peixe-boi amazônico. Durante a varredura abdominal foi possível visualizar as características dos órgãos obtendo resultados satisfatórios neste estudo, concluindo ser uma técnica eficiente para avaliação de determinados órgãos abdominais em peixe-boi amazônico. Entretanto, outras estruturas não foram identificadas principalmente pelo tempo reduzido, muita gordura e gases nos intestinos dos animais
\end{abstract}

Palavras-chave: peixe-boi, ultrassom, abdominal.

\section{Introduction}

Research on wild animals has increased because of the need for knowledge on species' biology, anatomy, and physiology (Alves et al., 2007). The Amazonian manatee (Trichechus inunguis), currently classified as endangered, is the only freshwater siren on the IUCN Red List and

is considered vulnerable (Marmontel et al., 2016); as a result, extensive studies on these animal's life histories have become more common owing to the need for captive breeding of these animals to attempt their reintroduction into the wild. Thus, studies related to reproductive biology

*e-mail: carlos.sousa@ufac.br

Received: January 15, 2021 - Accepted: March 30, 2021

This is an Open Access article distributed under the terms of the Creative Commons Attribution License, which permits unrestricted use, distribution, and reproduction in any medium, provided the original work is properly cited. 
(Best, 1982; Marmontel et al., 1992; Amaral et al., 2009; Amaral et al., 2010b), morphometric parameters in length-weight relation (Amaral et al., 2010a), and urinary parameters (Pantoja et al., 2010) have been carried out.

Anatomical studies (Moura et al., 2007; Previatto and Posso, 2015) support that morphological information allows us to understand how animals interact with their natural environment or in captivity, thereby being able to use it in favor of the preservation of the species. However, anatomical studies on T. inunguis are scarce (Colares, 1994), and the morphological characterization of vascular organs and structures mainly refers to T. manatus (Snipes, 1984, Reynolds and Rommel, 1996, Rommel et al., 2001, Rommel and Caplan, 2003), a marine species.

Diagnostic imaging has wide usage and is a rising technique in the context of veterinary medicine because it is a method of prevention, diagnosis, and control of diseases; in particular, ultrasonography is a non-invasive method of assessing the internal organs, thereby diminishing the consequences of stress (Alves et al., 2007).

Therefore, it is essential to know the ultrasound anatomy to identify the standard pattern or to diagnose diseases, as this method allows us to observe the morphophysiological evaluation of structures and internal organs. As a result, this study aimed to standardize the examination technique and describe the ultrasound findings of the liver, gallbladder, stomach, urinary bladder, and the subcutaneous tissue of the abdominal region in the Amazonian manatee (Trichechus inunguis), providing study tools to aid future research on this species.

\section{Material and Methods}

This study was conducted under the authorization for scientific purposes by the Ministry of Environment (MMA) and the Chico Mendes Institute for Biodiversity Conservation (ICMBio). It was approved by the Ethics Committee on Animal Use of the Federal Rural University of Amazonia (UFRA) with protocol 010/2014, 23084.0071362014-77.

Eighteen animals were used, nine males and nine females, acquired by either seizure and rescue by the Brazilian Institute of Environment and Renewable Natural Resources (IBAMA). To select the animals included in this study, routine tests were performed to select the healthiest manatees.

Ultrasound examination was performed by abdominal scan to visualize and characterize the abdominal organs using a portable ultrasound device (Chison 8100) with a convex transducer (3.5 and $5.0 \mathrm{MHz}$ ).

Each animal's examination lasted a maximum of $15 \mathrm{~min}$. To avoid or prevent handling stress, the animals' breathing intervals were closely monitored. When breathing did not happen voluntarily or breathing difficulties were observed, the animal was tilted, and water was poured over its snout, stimulating the breathing reflex.

Each organ received its own evaluation method to better adapt the examination and evaluation criteria described: measuring size, wall thickness, contour, edges, echogenicity, echotexture, and characterization of the content.

\section{Results and Discussion}

\subsection{Ultrasound exam}

The abdominal ultrasound study provided high-resolution images of the liver, gallbladder, stomach, urinary bladder, and subcutaneous tissue of a healthy Trichechus inunguis. Other structures were not primarily identified owing to the lack of time and the large amounts of fat and gases in the animals' intestines (Dierauf and Gulland, 2001).

We chose to limit the exam time to a maximum of 15 minutes owing to the observation of respiratory effects in animals contained during this period. Thus, no animal had respiratory problems on the day of the test. However, the scan of the entire abdominal region was limited owing to the need to capture images of various organs in a short period of time.

\subsubsection{Liver and Gallbladder}

For liver evaluation, the transducer was positioned in the subcostal region acoustic subxiphoid window, moving it laterally to the right antimere to identify the gallbladder and then along the costal margin to evaluate hepatic lobes. Thereby, the entire parenchymal liver was evaluated using the technique described by Ribeiro (2012). We tried to obtain images of the hepatic vascular architecture, but this was only possible in one animal.

In the images, boundaries and anatomical references were identified during the liver evaluation. In particular, the hyperechoic line of the diaphragm boundary was determined as the cranial to the liver. The parenchyma and liver surface and the gallbladder and hepatic veins were evaluated by scanning the middle region and lateral abdomen in the transverse and sagittal planes for a complete evaluation of the liver surface.

The liver occupies the entire cranial abdomen in contact with the diaphragm. The gallbladder is between the right and square medial lobes, consistent with studies in dogs, cats (Kealy et al., 2005), and primates (Alves et al., 2007).

In the Amazonian manatee, the liver is hypoechoic and has a homogeneous echotexture throughout its length, dotted with medium intensity, regular contours, and edges. Its limits are defined anteriorly by the diaphragmatic surface, both right and left lobes, and caudal to the left lobe by the stomach (Figure 1 ). These results are similar to those reported by Carvalho (2004) regarding dogs and cats, who found that normal liver parenchyma has a homogeneous echotexture that is slightly coarser than the spleen echogenicity that is relative to the spleen and renal cortex. Contrarily, the liver echogenicity of coatis (Nasua nasua) (Ribeiro, 2012), and capuchin monkeys (Cebus spp.) was found to be average, even though in some primates this organ has been shown to be hyperechoic (Alves et al., 2007).

In manatees, the hepatic vascular architecture has visible vascular walls, with a hyperechoic appearance, turning to a coarse echotexture, with a visible delimitation of hepatic vessels (hepatic veins). The literature describes the portal vein of dogs and cats as a hyperechoic wall composed of fibrous and fat tissue, which is easily distinguishable in the 


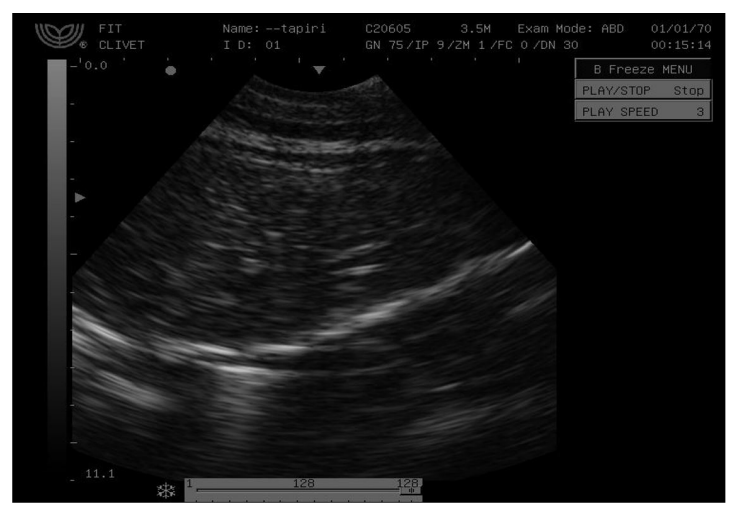

Figure 1. Sonographic aspects of normal liver in Amazonian manatee, there is hyperechoic line corresponding to the diaphragm, liver hypoechoic, homogeneous, speckled with medium intensity with regular contours and edges.

anechoic hepatic veins (Carvalho, 2004), which are next to the caudal cava vein and in close view of the diaphragm that receives the hepatic veins as described in capuchin monkeys (Alves et al., 2007).

Regarding the gallbladder of manatees, we can conclude that when filled, it shows an anechoic content with no sediment and regular thin walls, similar to that observed in dogs and coatis (Carvalho, 2004; Ribeiro, 2012). The gallbladder in cetaceans are large and easily observed through ultrasonography (Dierauf and Gulland, 2001). The manatee's gallbladder is similar; it has an average thickness of $0.36 \mathrm{~cm}$, with a minimum thickness of $0.2 \mathrm{~cm}$, and maximum thickness of $0.47 \mathrm{~cm}$, which is similar to dogs whose wall is between 0.1 to $0.5 \mathrm{~cm}$ in thickness (Carvalho, 2004).

\subsubsection{Stomach}

The Amazonian manatee stomach was studied by ultrasound examination in the cranial abdomen to the left of the midline, limited cranially by the liver (Froes, 2004). The stomach was mostly filled with gas, creating reverberation and posterior acoustic shadowing, with a fine hypoechoic wall and poor delimitation of the stomach villi.

Proper evaluation of the gastrointestinal tract of non-human primates demonstrated more limitations compared to dogs and cats (Newell et al., 1999). These animals have a higher amount of gas content, predominantly in the stomach, making the assessment a difficult task, which may be explained by its potentially fermentative diet (Souza et al., 2014). Similar manatees, a monogastric species, have a diet based on aquatic plants.

\subsubsection{Urinary bladder}

In Manatees, the urinary bladder is in the ventrocaudal abdominal cavity, just above the genital opening of females (the study did not use males) (Dierauf and Gulland, 2001). In wild animals, it is common to capture or restrain, and animals urinate owing to stress handling. As the manatees were manipulated before the ultrasound examination to perform the biometrics, it was common for these animals to urinate, making it difficult to observe the bladder owing to it being deflated, paired with the presence of adjacent fat blocking the image.

The sonographic appearance of the urinary bladder in manatee resembles other domestic and wild animals. Using ultrasound shows regular fillings with content ranging from anechoic and hypoechoic, regular contour, and a wall with three layers, composed of a serous layer, more external and hyperechoic, muscle layer characterized as hypoechoic, and the innermost layer of the bladder wall, which is the hyperechoic submucosa. In this animal, the entire wall was $0.2 \mathrm{~cm}$ in thickness (Figure 2). Similar to that observed in dogs and cats (Carvalho, 2004), quatis (Ribeiro, 2012), and capuchin (Alves et al., 2007).

\subsubsection{Subcutaneous}

In this study, we identified four distinct layers in the study of the ventral abdomen of manatee through ultrasound, corresponding from the innermost to the outermost layer, respectively: skin, characterized as hyperechoic and extremely thin; fat - too hyperechoic corresponding to the subcutaneous tissue; muscle - hypoechoic; peritoneum hyperechoic, corresponding to thinner and internal layer, in contact with the abdominal organs. In some images, more than four layers, between five and up to a total of twelve, suggesting significant subdivisions of the layers described (Figure 3), but histological studies are necessary to support the subcutaneous differentiation. These data were initially described as ultrasonographic findings for later analysis and description of these layers.

The manatees are capable of fasting for extended periods of time, using their fat reserves as a source of energy (Pazin, 2010). As such, ultrasound evaluation of the body fat layer in Trichechus inunguis could provide an interesting method to assess the physical conditions of each individual. This was also observed in this study, especially in larger animals, where the fat deposit is proportional to the size when healthy, thereby hindering the formation of the image.

Ultrasound is an indirect method that is sensitive, non-invasive, and easy to use for assessing body condition. It can be used to monitor areas with fat deposits and changes in the normal composition during dietary intervention (Mooroka et al., 2001). Stien et al. (2003) concluded that measuring the fat layer via ultrasound is extremely sensitive and suitable for studying large vertebrates, thereby identifying underfed or overfed animals (Rodrigues et al., 2011).

Wilkinson and McEwan (1991) measured various tissue interfaces according to depth, measuring the fat layer that lies between the dermis and the cutaneous muscle, which is generally thicker than the lumbar region. Although the results showed significant variations between individuals, this difference was not as pronounced among different parts of the animal body.

We agree with the description of Carvalho et al. (2015), mentioning that ultrasound is an effective method to measure the subcutaneous fat layer in mammals, especially manatees, knowing that they are animals that depend on 


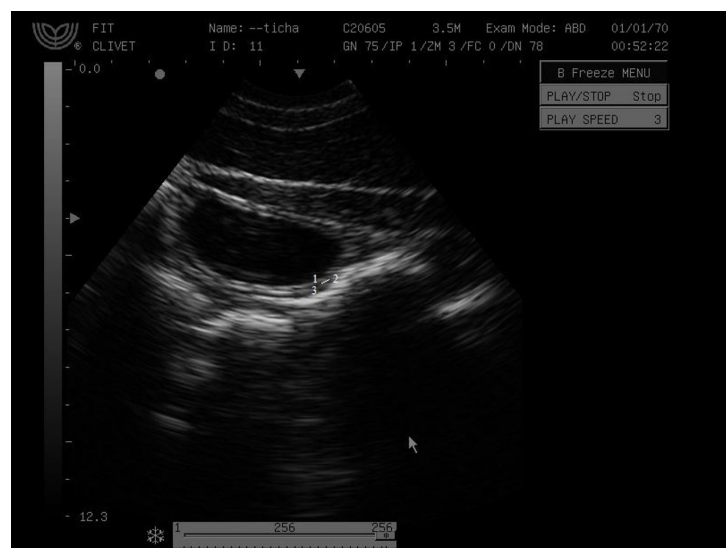

Figure 2. Sonographic appearance of the urinary bladder of the Amazonian manatee, being observed anechoic to hypoechoic content, regular contour with three layers of the wall, represented by the numbers 1 (submucosal layer), 2 (muscle layer) and 3 (serous layer).

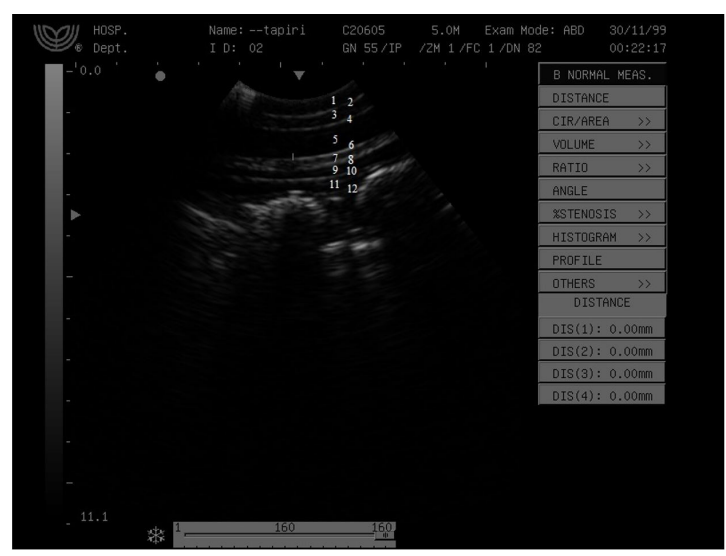

Figure 3. Sonographic image with 12 different layers displayed on the ventral abdomen of manatee.

their fat reserves during the low water season of Amazonian rivers, thereby causing a scarcity of food .

According to the results, the methodology used was adequate for the abdominal ultrasound of the liver, gall bladder, stomach, urinary bladder, and subcutaneous tissue of the Amazonian manatee. It is a non-invasive technique that provides real-time images. For a more detailed assessment, we suggest analyzing a smaller number of organs in the appropriate amount of time to obtain a more precise and detailed anatomical description, assisting in the pathological diagnosis.

\section{References}

ALVES, F.R., COSTA, F.B., AROUCHE, M.M.S., BARROS, A.C.E., MIGLINO, M.A., VULCANO, L.C. and GUERRA, P.C., 2007. Avaliação ultrasonográfica do sistema urinário, fígado e útero do macaco-prego,
Cebus apela. Pesquisa Veterinária Brasileira, vol. 27, no. 9, pp. 377382. http://dx.doi.org/10.1590/S0100-736X2007000900004.

AMARAL, R.S., ROSAS, F.C.W., VIAU, P., D’AFFONSECA NETO, J.A., DA SILVA, V.M.F. and OLIVEIRA, C.A., 2009. Noinvasive monitoring of androgens in male Amazonian manatee (Trichechus inunguis): biologic validation. Journal of Zoo and Wildlife Medicine, vol. 40, no. 3, pp. 458-465. http://dx.doi.org/10.1638/2008-0111.1. PMid: 19746860.

AMARAL, R.S., DA SILVA, V.M.F. and ROSAS, F.C.W., 2010a. Body weight/length relationship and mass estimation using morphometric measurements in Amazonian manatees Trichechus inunguis (Mammalia: sirenia). Marine Biodiversity Records, vol. 3, no. e105, pp. 1-4. http://dx.doi.org/10.1017/ S1755267210000886.

AMARAL, R.S., LUCCI, C.M., ROSAS, F.C.W., DA SILVA, V.M.F. and BÁO, S.N., 2010b. Morphology, morphometry and ultrastructure of the amazonian manatee (Sirenia: Trichechidae) spermatozoa. Zoologia, vol. 27, no. 6, pp. 1014-1017. http://dx.doi.org/10.1590/ S1984-46702010000600025.

BEST, R.C., 1982. Seasonal breeding in the Amazonian manatee, Trichechus inunguis (Mammalia: sirenia). Biotropica, vol. 14, no. 1, pp. 76-78. http://dx.doi.org/10.2307/2387764.

CARVALHO, C. F., 2004. Ultra-sonografia em pequenos animais. São Paulo: Roca, 365 p.

CARVALHO, L.A.R., 2015. Estudo comparativo entre quatro métodos de aferição de condição corporal em cães. Lavras: Universidade Federal de Lavras, 69 p. Dissertação de Mestrado em Ciências Veterinárias.

COLARES, F.A.P., 1994. Aspectos morfológicos do estômago do peixeboi da Amazônia Trichechus inunguis (Mammalia: Sirenia). Belo Horizonte: Universidade Federal de Minas Gerais, 81 p. Dissertacão de Mestrado em Zootecnia.

DIERAUF, L.A. and GULLAND, F.M.D., 2001. CRC handbook of marine mammal medicine. 2nd ed. Boca Roton: CRC Press, 1063 p. http://dx.doi.org/10.1201/9781420041637.

FROES, T.R., 2004. Ultrassonografia do trato gastrointestinal. In: C.F. CARVALHO. Ultrassonografia em pequenos animais. São Paulo: Roca, pp. 147-162.

KEALY, J.K., MCALLISTER, H. and GRAHAN, J.P., 2005. Radiologia e ultrassonografia do cão e do gato. 3. ed. São Paulo: Manole, 436 p.

MARMONTEL, M., DE SOUZA, D. and KENDALL, S., 2016. Trichechus inunguis. Cambridge: The IUCN Red List of Threatened Species. https://dx.doi.org/10.2305/IUCN.UK.2016-2.RLTS. T22102A43793736.en.

MARMONTEL, M., ODELL, D.K. and REYNOLDS III, J.E., 1992. Reproductive biology of South American manatees. In: W.C. HAMLETT. Reproductive biology of South American vertebrates. New York: Springer-Verlag, pp. 295-312. http://dx.doi. org/10.1007/978-1-4612-2866-0_20.

MOROOKA, T., NIIYAMA, M., UCHIDA, E., UEMURA, M., MIYOSHI, K. and SAITO, M., 2001. Measurement of the back fat layer in beagles for estimation of obesity using two-dimensional ultrasonography. Journal of Small Animal Practice, vol. 42, no. 2 , pp. 56-59. http://dx.doi.org/10.1111/j.1748-5827.2001.tb01992.x.

MOURA, C.E.B., ALBUQUERQUE, J.F.G., MAGALHÃES, M.S., SILVA, N.B., OLIVEIRA, M.F. and PAPA, P.C., 2007. Análise comparativa da origem do plexo braquial de catetos (Tayassu tajacu). Pesquisa Veterinária Brasileira, vol. 27, no. 9, pp. 357-362. http://dx.doi. org/10.1590/S0100-736X2007000900001.

NEWELL, S.M., GRAHAMM, J.P., ROBERTS, G.D., GINN, P.E. and HARRISON, J.M., 1999. Sonography of the normal feline gastrointestinal tract. Veterinary Radiology E Ultrasound, vol. 
40, no. 1, pp. 40-43. http://dx.doi.org/10.1111/j.1740-8261.1999. tb01837.x.

PANTOJA, T.M., DA ROSAS, F.C., DOS SILVA, V.M. and SANTOS, A.M., 2010. Urinary parameters of trichechus inunguis (Mammalia, Sirenia): reference values for the Amazonian Manatee. Brazilian Journal of Biology = Revista Brasileira de Biologia, vol. 70, no. 3, pp. 607-615. http://dx.doi.org/10.1590/S1519-69842010000300018. PMid:20730348.

PAZIN, M.G.G., 2010. Ecologia alimentar do peixe-boi da Amazônia (Trichechus inunguis) (Sirenia, Trichechidae) nas reservas de desenvolvimento sustentável Mamirauá e Amanã. Amazonas: Instituto Nacional de Pesquisas da Amazônia, 53 p. Dissertação de Mestrado em Ciências Biológicas.

PREVIATTO, D.M. and POSSO, S.R., 2015. Jaw musculature of Cyclarhis gujanensis (Aves: vireonidae). Brazilian Journal of Biology $=$ Revista Brasileira de Biologia, vol. 75, no. 3, pp. 655-661. http://dx.doi. org/10.1590/1519-6984.20113. PMid:26421766.

REYNOLDS, J.E. 3rd and ROMMEL, S.A., 1996. Structure and function of the gastrointestinal tract of the Florida manatee, Trichechus manatus latirostris. The anatomical Record, vol. 245, no. 3, pp. 539-558. http://dx.doi.org/10.1002/(SICI)10970185(199607)245:3<539::AID-AR11>3.0.CO;2-Q..

RIBEIRO, R.G., 2012. Ultrassonografia abdominal em quatis (Nasua nasua Linnaeus 1766) hígidos: descrição anátomo-topográfica. Goiânia: Universidade Federal de Goiás, 56 p. Dissertação de Mestrado em Ciência Animal.

RODRIGUES, P.G., RAYMUNDO, C.M., SOUZA, J.C., MIRANDA, M.C.M.G. and REZENDE, A.S.C., 2011. Gordura corporal e eficiência reprodutiva em éguas doadoras de embrião mangalarga marchador. Ciência e Agrotecnologia, vol. 35, no. 5, pp. 10021008. http://dx.doi.org/10.1590/S1413-70542011000500019.
ROMMEL, S.A. and CAPLAN, H., 2003. Vascular adaptations for heat conservation in the tail of Florida manatees (Trichechus manatus latirostris). Journal of Anatomy, vol. 202, no. 4, pp. 343-353. https://doi.org/10.1046/j.1469-7580.2003.00170.x..

ROMMEL, S.A., PABST, D.A. and MCLELLAN, W.A., 2001. Functional morphology of venous structures associated with the male and female reproductive systems in Florida manatees (Trichechus manatus latirostris). The Anatomical Record, vol. 264, no. 4, pp. 339-347. http://dx.doi.org/10.1002/ar.10022. PMid:11745089.

SNIPES, R.L., 1984. Anatomy of the cecum of the West Indian manatee, Trichechus manatus (Mammalia, Sirenia). Zoomorphology, vol. 104, no. 2, pp. 67-78. http://dx.doi.org/10.1007/BF00312020.

SOUZA, A.C., LANGE, R.R., PRZYDZIMIRSKI, A.C., CASTRO, P.H.G., PASCOLI, A., JÚNIOR, J.C.S., and FROES, T.R., 2014. Avaliação ultrassonográfica e mensurações das glândulas adrenais em primatas não humanos neotropicais: mico-de-cheiro (Saimiri sciureus), macaco-da-noite (Aotus azarae infulatus) e bugio-ruivo (Alouatta guariba clamitans). Pesquisa Veterinária Brasileira, vol. 34, no. 9, pp. 903-910. http://dx.doi.org/10.1590/S0100736X2014000900016.

STIEN, A., IRVINE, R.J., LANGVATN, R. and ROPSTAD, E., 2003. Evaluation of ultrasound scanning as a method for measuring subcutaneous fat in Svalbard reindeer. Rangifer, vol. 23, no. 2, pp. 71-73. http://dx.doi.org/10.7557/2.23.2.363.

WILKINSON, M.J.A. and MCEWAN, N.A., 1991. Use of ultrasound in the measurement of subcutaneous fat and prediction of total body fat in dogs. The Journal of Nutrition, vol. 121, no. 11, (suppl.), pp. 47-50. http://dx.doi.org/10.1093/jn/121.suppl_11. S47. PMid:1941237. 